${ }^{(*)}$ Realizador, historiador y crítico de Cine. Profesor de Historia y Estética del Cine en la Universidad de Palermo y en la Escuela Nacional de Experimentación Cinematográfica (INCAA). Colaborador de la revista $\mathrm{N}$, productor y conductor de espacios radiofónicos y televisivos sobre cine.

Resumen: Además de las transposiciones y citas borgeanas en filmes de Torre Nilsson, Saura, Mick Jagger, Scorsese, Godard, Christensen, Bertolucci, Hugo Santiago, Chabrol, Bielinsky, Mugica, Cozarinsky, Javier Torre, Bauer, Narcisa Hirsch o Desanzo; encontramos las opiniones de Borges como crítico cinematográfico sobre Groucho Marx, Eisenstein, Ford, Soffici, Orson Welles, Hitchcock, el doblaje, el cine argentino; su preferencia por los westerns y por el cine de gangsters del barroco vienés Von Sternberg -acaso parientes hollywoodenses de sus cuchilleros porteños-, y su labor como guionista. Defensor del cine clásico antes que del "nuevo cine" que se interesó en él, Borges hizo cine desde su literatura. El modelo, gramática o sistema narrativo del cine (¿magia?) que ordena el caos en el encuadre y el montaje atraviesan su obra, tan inclinada también por mundos proyectados y espejismos reveladores.

Palabras claves: circularidad - citas - cosmogonía - escenas - espejos - laberintos - montaje - síntesis.

[Resúmenes en inglés y portugués en la página 42]

Explorar la relación entre Borges y el cine nos conduce a uno de sus laberintos y al extravío. Por lo tanto, no debe sorprender que el inicio del recorrido sea a contramano, es decir, posponiendo la enumeración cronológica y enciclopédica de las transposiciones, para detectar que el cine borgeano está en su propia literatura, en la obra de un escritor cinéfilo obsesionado por los sistemas ficcionales de representación, las alteraciones de tiempo y espacio, el montaje, la sintaxis y las imágenes alucinatorias o especulares. Borges subvierte el refrán y su palabra vale mil imágenes. Sin embargo, y con diversos resultados, intentaron poner sus textos en imágenes creadores tan distintos como Bertolucci, Chabrol, Godard, Saura, Mick Jagger, Torre Nilsson, Hugo Santiago, René Mugica, Desanzo, Bauer o Scorsese y las numerosas "biopic" que no resistieron la tentación de contar su vida mezclada con sus ficciones -tal vez, porque como sentenció Sylvia Molloy "las biografías solo se parecen a la vida en que se nos escapan de las manos" y porque "la vida es siempre, necesariamente, relato" ${ }^{1}$

Como buen laberinto, este peregrinaje entre letras y celuloide solo aceptará dos finales: la triste catalogación que mata como el Minotauro, o el hallazgo de una fuga, un sendero que se bifurca en ese jardín cuando se cruzan los círculos de las ruinas borgeanas con la circularidad de las películas que aún giran en sus carretes proyectando fantasmagorías en nuestras cavernas oscuras del siglo XXI. La inclinación a invocar fantasmas no ha sido ajena a Borges, ni al cine, ni a estás páginas. 


\section{Crítico, guionista, cinéfilo, actor}

Por una parte se encuentra la producción de Borges como crítico de cine en las revista Sur, El Hogar, en sus ensayos reunidos en "Discusión” y diversas entrevistas, donde ofreció opiniones muy personales sobre Hitchcock (de quien admiraba Psicosis), Welles (Citizen Kane se lo antojaba "genial en el sentido más oscuro y alemán de la palabra”), Eisenstein (de quien valoraba Alejandro Newsky), Groucho Marx (al que imitó en un reportaje donde la periodista Gloria López Lecube le decía que era más famoso que Miguel Angel Solá, y respondió que no sabía quién era ese actor pero que si se tratara de Emile Zola sí sería muy llamativo porque había muerto hacía 100 años)².

No se ahorró ironías sobre el doblaje ("ya que hay usurpación de voces ¿por qué no también de figuras? ¿cuándo veremos directamente a Juanita González en vez de Greta Garbo en el papel de la Reina Cristina de Suecia?), y supo perjudicarse -como en otros campos- al comentar cine argentino ("he visto una gran película argentina, es decir, una de las peores del mundo"), y aunque elogió Prisioneros de la tierra y La fuga, precisó en la revista Sur: "Entrar en un cinematógrafo de la calle Lavalle y encontrarme (no sin sorpresa) en el Golfo de Bengala me parece preferible a entrar en ese mismo cinematógrafo y encontrarme (no sin sorpresa) en la calle Lavalle. Confieso esto para que nadie achaque a turbio patriotismo mi vindicación de un film argentino. Idolatrar un adefesio porque es autóctono, dormir por la patria, agradecer el tedio cuando es de elaboración nacional, me parece un absurdo". Según su viuda, la escritora y profesora María Kodama, además de su veneración por la primera etapa hollywoodense del director vienés y barroco Joseph Von Sternberg (especialmente La ley del hampa, de 1927, y Los muelles de Nueva York, de 1928), Borges apreciaba solo dos películas del sueco Ingmar Bergman, La fuente de la doncella y El séptimo sello. En este último film disfrutaba del asunto medieval metafísico y del juego de ajedrez con la muerte. Kodama recuerda haberlo acompañado repetidas veces a funciones de El hombre elefante, de David Lynch, con ambiente victoriano como marco de la relación entre un médico sensible y un deforme tratado como freak detrás de cuya apariencia late una enorme humanidad; la épica Lawrence de Arabia y los musicales Pink Floyd, the wall, -cuya banda sonora enmarcaba las celebraciones de sus cumpleaños-, y Amor sin barreras, de la que le atraía la historia de pandillas neoyorquinas, que a su vez era una versión de Romeo y Julieta, de Shakespeare.

Por su adelantada valoración del cine de aventuras, a la hora de confrontarse con las adaptaciones fílmicas de sus libros prefirió "Hombre de la esquina rosada” donde Múgica concretó una obra personal dentro del "cine de géneros" y del modelo clásico de representación; a la derivación que en "cine de autor" tuvo su "Emma Zunz" con Días de Odio de Torre Nilsson, de la que hasta cuestionó el título, ya que le parecía que las tragedias clásicas deben conservar por título el nombre de sus protagonistas.

Su admiración hacia el western lo llevaría a declarar: "en tiempos en los que los literatos han descuidado sus deberes épicos, el mundo ha podido conservar esa tradición gracias a Hollywood” ${ }^{3}$. De John Ford, sin embargo, prefería El delator, que trataba sobre uno de sus temas favoritos: la traición, pero de lo que no queda duda alguna es que Borges defendía el modelo clásico de narración cinematográfica y se posicionaba contra el "nuevo cine" que intentaba quebrar o dinamitar ese orden.

En una época en que el cine no tenía el prestigio o status cultural que luego alcanzó, Borges reconoció (en el prólogo de Historia Universal de la Infamia, 1935) que sus ejercicios de ficción derivaban del cine de gángsters de Von Sternberg, y al ofrecer un perfil de su labor, se indica en Antología de la literatura fantástica: "escribe en vano argumentos para el cinematógrafo". Esto último consumado en varios guiones suyos con Bioy como "Los orilleros", "El Paraíso de los creyentes” y dos películas de Hugo Santiago, Los otros e Invasión. 
A la filmografía de Borges debe sumarse una curiosa intervención como actor, interpretando el personaje del bibliotecario Dahlmann en la versión fílmica de "El sur", cuando al final sale a la llanura empuñando un cuchillo, realizada por José Luis Di Zeo bajo el título Borges, un destino sudamericano. El director ha recordado que Borges llegó al set, en pleno campo, una fría mañana de junio de 1975 y que mitigó el miedo con alguna bebida espirituosa para jugar su escena con el puñal, tras un frustrado ensayo en el que enterró su bastón en una especie de vizcachera. Según Di Zeo es posible que haya accedido a interpretar brevemente a Dalhmann porque se trataba del cuento al que consideraba más autobiográfico ${ }^{4}$.

La cinefilia de Borges se constata en una confesión personal, recogida en el documental de Montes Bradley "Harto de Borges": "Se equivocan los que piensan que no he conocido el amor. Puedo afirmar que he vivido enamorado. El primer amor de mi vida fue una actriz, Ava Gardner. Solía ver sus películas dos veces por día y apenas terminaba la función deseaba que llegara el día siguiente para volver a verla. El amor exige pruebas, pruebas sobrenaturales". También se le han reconocido pasiones por Asta Nielsen y Greta Garbo.

La influencia del lenguaje cinematográfico en su estilo literario se hace presente en sus soluciones narrativas inclinadas por la síntesis y el montaje -del relato paralelo y planos enfáticos a lo Griffith al montaje de choque de Eisenstein-; y en varias de sus obsesiones temáticas -por espejos, dobles, mundos proyectados, mitología circular-. Allí están los espejismos reveladores de universos visuales que se ofrecen como ordenamiento del caos, "Tlön, Uqbar, Orbis, Tertius" o el acceso a "todas las imágenes sin superponerse" que pueden sucederse en "El Aleph". A propósito de todo lenguaje expresó que "el idioma es un sistema artificial que no tiene nada que ver con lo que llamamos realidad, es decir, con esa sucesión de percepciones y distracciones que nos parecen la realidad".

En "La otra aventura", Bioy Casares se preguntaba "si parte del Buenos Aires que conocemos no consistirá en episodios y personajes de una novela inventada por Borges, ya que su palabra confiere a la gente más realidad que la vida misma".

La palabra en Borges remite a la imagen, en tanto es revelación, ya sea en la sucesión de visiones de "El Aleph", como en "La escritura de Dios", donde el sacerdote azteca encarcelado intenta descifrar el mensaje de Dios mientras no despierta a la vigilia sino a un sueño anterior y al unirse con la divinidad (con el universo) proclama:

Yo vi una Rueda que estaba en todas partes, a un tiempo. Entretejidas, la formaban todas las cosas que serán, que son y que fueron, y yo era una de las hebras de la trama total. Me bastaba ver para entenderlo todo. Vi el universo y vi los íntimos designios del universo. Vi el dios sin cara que hay detrás de los dioses. Es una fórmula de catorce palabras casuales. Me bastaría decirla para abolir esta cárcel de piedra, para ser joven, para ser inmortal. Cuarenta sílabas, catorce palabras, y yo Tzinacán, regiría las tierras que rigió Moctezuma. Pero yo sé que nunca diré esas palabras, porque ya no me acuerdo de Tzinacán. Quien ha entrevisto el universo no puede pensar en un hombre, en sus triviales dichas o desventuras, aunque ese hombre sea él. Ese hombre ha sido él y ahora no le importa.

La búsqueda de sistemas, artificios, ajedrez, laberintos, son para Borges una esperanza de salvación del caos, ya que vivimos en la perplejidad pero rastreando un plan, un diseño, que puede ser divino o demoníaco, pero que nos haga parte de una arquitectura. El arte nos permite asomar indirectamente 
a ese orden metafísico donde quedan abolidos el tiempo y el espacio, lo que es preferible a alcanzarlo directamente pues "soñamos con el infinito pero de alcanzarlo nos destruiría".

\section{El tiempo y la eternidad}

El periodismo kitsch asegura sin pudor que el cine ofrece un beso de inmortalidad a sus estrellas pero hay algo de cierto en que desafía el tiempo, incluye cierta promesa de eternidad, hace presente el pasado y proyecta al futuro aquello que ya no está, por lo que aún seducen desde la pantalla muchos "muertos vivos" o resucitados por la proyección. También para el cineasta, como para cualquier artista con su obra, existe la ilusión de perpetuidad, de que su muerte sea menos muerte, de que algo suyo lo sobreviva.

"Yo sospecho que Borges ha recibido el infinito de la literatura" dice Blanchot ${ }^{5}$, y Borges llega a la eternidad como Cartaphilus en "El inmortal"; concentra años en un minuto en "Emma Zunz" o dilata un segundo en años. A esa lógica espacio-temporal tan presente en la gramática del cine, se suman la abolición del espacio y tiempo a la que se entrega el espectador durante la proyección con lo que eso implica de disolución de la realidad desde una muerte interior y platónica.

Abundan las citas a Platón y su "mito de la caverna" como antecedente del cine, aquella situación de los hombres sentados de espaldas a la luz de la entrada y frente a una pared en la que se proyectan las sombras que los hombres creen reales, pero también es platónica la idea de que todo conocimiento, toda novedad, no es sino reminiscencia, conocer es recordar algo que se había olvidado. A esa memoria abarcadora y suprema, como al manantial de palabras e imágenes del que se sirven la literatura y el cine para que el mundo cumpla su destino: ser representado; se aproxima el atributo divino que Borges describe en su soneto "Everness":

Dios, que salva el metal, salva la escoria

y cifra en su profética memoria

las lunas que serán y las que han sido.

La vastedad del tiempo, pasado y futuro, ya está contenida en Dios, que es la suma del tiempo, o de la corrupción de lo que muta (tiempo y espacio) nos salva la muerte, en su poema "Los enigmas" como "un orbe sin antes, ni después, ni cuándo". Según algunos estudiosos "esa condena de lo material casa bien con la adscripción de Borges al idealismo berkeleyano, el mundo no deja de ser una maraña de percepciones instantáneas. Con semejantes dosis de platonismo destructivo, Borges ha sido capaz de crear los mejores de sus relatos" ${ }^{6}$.

También Shakespeare, a través de Macbeth, describía la vida como "leve candela (...), un cuento contado por un idiota(...), un relato lleno de ruido y de furia que nada significa."

En ese platónico abandono o destrucción del engañoso mundo sensible para ascender a lo que en "Poema conjetural" define como "insospechado rostro eterno", se cruza el rito nocturno de la proyección (donde la pantalla nos absorbe como a la luz -al contrario que la televisión que emite luz y nos refracta).

Allí nos permitimos dejar de ser nosotros mismos para ser otros, todos, nadie, o dicho por Borges: "En breve, seré todos, estaré muerto" o en el prólogo de su "Obra poética" expresa: "es trivial y fortuita la circunstancia de que seas tú el lector de estos ejercicios y yo su redactor", como asimismo en "La forma de la espada" escribe: "lo que hace un hombre es como que lo hicieran todos los hombres. Yo soy los otros, cualquier hombre es todos los hombres" y en "El inmortal" propone que "un hombre es los otros, o más exactamente, la reducción de todos los individuos a una identidad general y suprema 
que los contiene a todos y que hace, a la vez, que todos estén contenidos en cada uno de ellos". En el sueño colectivo al que asistimos en las salas oscuras, en el que acaso vivimos un sueño dirigido, o en el que quizás también somos soñados; junto con cierta pérdida de la conciencia nos asaltaría otro estado de percepción, según lo advertía Rilke, quien no consideraba a los hombres "en el mundo" sino "frente al mundo" y para quien "Somos abejas de lo invisible: nosotros bebemos desesperadamente la miel de lo visible para acumularla en la gran colmena de oro de lo invisible" 7 O regresando a los hermosos versos de "Everness": "Solo del otro lado del ocaso/verás los arquetipos y esplendores", recordando el significado de Arque: origen y tipos: modelos, los modelos originales, los que siempre existieron, los paradigmas, el acceso a la eternidad como categoría donde el tiempo ya no existe.

\section{Una ilusión de cosmos}

Como señaló Edgardo Cozarinsky en su libro Borges y el cine, el escritor encuentra en libros y películas "un diseño que permita la ilusión del cosmos. Ficción suprema, Tlön cautiva y suplanta al universo real con el espejismo de un orden", ya que un pasaje de "Tlön, Uqbar, Orbis, Tertius" interroga:

¿Cómo no someterse a Tlön, a la vasta evidencia de un planeta ordenado? Inútil responder que la realidad también está ordenada. Quizá lo esté, pero de acuerdo a leyes divinas -traduzco: leyes inhumanas- que no acabamos de percibir. Tlön será un laberinto, pero un laberinto urdido por hombres destinado a que lo descifren los hombres.

Cine y literatura prometen un sentido dramático, estético, una lógica de espacio, tiempo y acción, que insinúan la existencia de una cosmogonía, el universo se explica como sistema, como relato y representación reveladora, su misión es ser contado, reconocerse como reflejo.

El descubrimiento y consagración a ese mundo proyectado, acaso paralelo, subvierte la idea de que se trata de una fantasmagoría que nos refleja en otra que nos ubica como reflejo, en todo caso, nos perturba si la reconocemos como sublime o trascendente en contraste contra nuestra inmanencia. Como la frase de Truffaut inspirada por otra de Hitchcock "el cine es más grande que la vida.. . porque se pueden suprimir las partes aburridas".

Durante la proyección nos indignamos, reímos o tememos por "creer" -suspensión de la incredulidad- en esos fantasmas que habitan la pantalla en la que ilusionamos movimiento por nuestra incapacidad óptica de descomponer la visión de cada fotograma fijo que allí desfila velozmente. Acto de fe que re-liga el mundo físico con el metafísico. Experiencia que a partir de una percepción engañosa de nuestros sentidos se convierte en mental, y en la que se impone la realidad de la imagen por sobre la imagen de la realidad.

Lo anterior se vincula específicamente con la concepción de estructuras especulares que presenta la literatura de Borges, donde toda imagen es reflejo de otra en un juego de espejos enfrentados, como un sinfín de apariencias que se vuelve sobre sí. En esa estructura circular está el hombre (El Hacedor) que se propone "un mapa del mundo poblado con montañas y peces, pero antes de morir descubre que ese paciente dibujo traza la imagen de su cara". A favor de la supresión de fronteras entre sueño y vigilia, algo que reconocía logrado por el cine, Borges descubre que toda literatura, por realista que se pretenda, no dejar de ser fantástica "porque, en el principio de la literatura está el mito, y asimismo en el fin" ("Parábola de Cervantes y de Quijote"). 
Así como John Ford le hace decir al personaje del periodista en "Yo maté a Liberty Valance": "en el Oeste, cuando la leyenda es más bella que la realidad, imprimimos la leyenda"; Bioy Casares y Borges proclaman sin complejos su predilección por el modelo clásico en el cine y en el prólogo de "Los Orilleros" y "El paraíso de los creyentes" afirman:

Los dos films que integran este volumen aceptan, o quisieron aceptar, las convenciones del cinematógrafo. No nos atrajo al escribirlos un propósito de innovación; abordar un género e innovar en él nos pareció excesiva temeridad. El lector hallará previsiblemente el boy meets girl y el happy ending, las peripecias arriesgadas y el feliz desenlace. Es muy posible que tales convenciones sean deleznables; en cuanto a nosotros, hemos observado que los films que recordamos con más emoción -los de Sternberg, los de Lubitsch- las respetan sin mayor desventaja. Por cierto que ambos films son románticos, en el sentido que los son los relatos de Stevenson. Los informa la pasión de la aventura y, acaso, un lejano eco de epopeya. Los orilleros fue el anhelo de cumplir con ciertos arrabales, con ciertas noches y crepúsculos, con la mitología oral del coraje y con la humilde música valerosa que rememoran las guitarras ${ }^{8}$.

Esta es una de las claves por las que la relación entre Borges y cine ha resultado conflictiva: el escritor adhería al rigor narrativo del cine clásico que, como la literatura, establecía un sistema u orden de representación; pero cuando sus textos comienzan a interesar a los cineastas, el cine se encontraba ya en plena transformación y cuestionamiento de los modelos tradicionales. El cine moderno, que estalla con la nueva ola francesa, no parecía interesado más que en dinamitar las convenciones que a Borges le parecían la garantía de respeto hacia los géneros y hacia la narración visual. Se trataba de un orden jaqueado y perdido a cambio de la innovación, el "autorismo", las rupturas; pero al que Bioy y Borges no estaban dispuestos a renunciar.

\section{Espejos y escenas}

Parece oportuno recordar aquí algunos versos del poema "Los Espejos” en El Hacedor:

Todo acontece y nada se recuerda en esos gabinetes cristalinos donde, como fantásticos rabinos, leemos los libros de derecha a izquierda. Claudio, rey de una tarde rey soñado, no sintió que era un sueño hasta aquel día en que un actor mimó su felonía con arte silencioso, en un tablado. Dios ha creado las noches que se arman de sueños y las formas del espejo para que el hombre sienta que es reflejo y vanidad. Por eso nos alarman. 
Y también la idea de la representación confiriendo sentido a lo azaroso en "La trama":

César, acosado por los impacientes puñales, descubre entre las caras y los aceros la de Marco Bruto, su protegido, acaso su hijo, y ya no se defiende y exclama: ¡¡Tú también, hijo mío!'. Shakespeare y Quevedo recogen el patético grito. Al destino le agradan las repeticiones, las simetrías; diecinueve siglos después, en el sur de la provincia de Buenos Aires, un gaucho es agredido por otros y, al caer, reconoce a un ahijado suyo y le dice con mansa reconvención `Pero, che!’. Lo matan y no sabe que muere para que se repita una escena.

Las propias contingencias de su vida quedan remontadas a una categoría poética. Ya sea su ceguera en "Poema de los dones", o su propia muerte en "Los Enigmas" ("El otro, el mismo"):

Yo que soy el que ahora está cantando seré mañana el muerto, el misterioso el morador de un mágico y desierto orbe sin antes, ni después, ni cuando. Así afirma la mística, me creo indigno del infierno o de la gloria pero nada predigo, nuestra historia cambia como las formas de Proteo ¿Qué errante laberinto, que blancura ciega de resplandor será mi suerte cuando me entregue el fin de esta aventura la curiosa experiencia de la muerte? Quiero beber su cristalino olvido ser para siempre, pero no haber sido.

Como pedían los expresionistas a sus creadores, como el cine: Borges no quiere ver sino tener visiones, alcanzar espejismos reveladores que nos justifiquen. Consagrarse a esos puentes nietzscheanos entre lo físico y lo metafísico, entre el presente y la eternidad.

En su ensayo "El arte narrativo y la magia" (Discusión 1932), hace convivir en la misma página a Joyce y Joan Crawford, y menciona "la infinita novela espectacular que compone Hollywood, un orden diverso la rige, la primitiva claridad de la magia".

Por el contrario, su desprecio por la insoportable arbitrariedad del mundo real queda plasmado en "El idioma analítico de John Wilkins (Otras Inquisiciones"):

El mundo -escribe David Hume- es tal vez el bosquejo rudimentario de un dios infantil, que lo abandonó a medio hacer, avergonzado de su ejecución deficiente; es la obra de un dios subalterno, de quien los dioses superiores se burlan. (Dialogues Concerning Natural Religión, V, 1779). Cabe ir más lejos; cabe sospechar que no hay universo en el sentido orgánico, unificador, que tiene esa ambiciosa palabra. Si lo hay, falta conjeturar su propósito, falta conjeturar las palabras, definiciones, etimologías, sinonimias, del secreto diccionario de Dios". 
En su auxilio llegarán las palabras y las imágenes por las que se preguntará adónde irán cuando los hombres duermen. Cine y literatura como umbrales que solo al ser cruzados explican lo que parecía azaroso e inútil.

\section{El otro, el doble}

Es intrínseca al cine su condición de ilusionismo, fantasmagoría, vampirización de la persona en personaje y del espectador absorbido por la pantalla para ser transportado a otra lógica espacio-temporal, más cercana a la de los sueños. El que mira se desdobla y proyecta en esas sombras hipnóticas, asoma a unas acciones y emociones que le serían insoportables en su vigilia. En la sala oscura accede a la zona de duda, a una zambullida controlada en las aguas del inconsciente y lo no codificado. Como indicaba Borges, en una fracción de tiempo se vive el paraíso y el infierno, y uno es todos los hombres.

Asimismo, el cineasta como el escritor se desdobla en su obra, su creación pasa a ser su criatura, una extensión de sí mismo que lo sobrevivirá. Algo de sí será para siempre y su muerte será menos muerte. Pero a la vez, esta creación humana en la que se siente un demiurgo, un fundador de mundos, un Dios, lo expone, a sus propios límites ante un orden superior; como en el cuento borgeano "El muerto" cuyo protagonista se cree dueño de su destino y del ajeno, mientras ya ha sido sentenciado; en tanto en el poema "Ajedrez II" versifica sobre las piezas del tablero:

(...) no saben que la mano señalada

del jugador gobierna su destino

no saben que un rigor adamantino

sujeta su albedrío y su jornada.

También el jugador es prisionero, (...)

de otro tablero de negras noches y blancos días

Dios mueve al jugador y este la pieza

qué Dios detrás de Dios la trama empieza

de polvo, tiempo, sueños y agonías.

pues él también es gobernado y pieza de un orden mayor, digamos de la historia para un ateo, o de Dios. En "El Golem" (El otro, el mismo), Borges conjuga estas ideas:

Si (como el griego afirma en el Cratilo)

el nombre es arquetipo de la cosa,

en las letras de 'rosa' está la rosa

y todo el Nilo en la palabra 'Nilo'.

Sediento de saber lo que Dios sabe,

Judá León se dio a permutaciones

de letras y a complejas variaciones

y al fin pronunció el Nombre que es la Clave

El cabalista que ofició de numen

a la vasta criatura apodó Golem;

estas verdades las refiere Scholem

en un docto lugar de su volumen. 
El rabí lo miraba con ternura

y con algún horror. ¿Cómo (se dijo)

pude engendrar este penoso hijo

y la inacción dejé, que es la cordura?

En la hora de angustia y de luz vaga,

en su Golem los ojos detenía.

¿Qué nos dirá las cosas que sentía

Dios, al mirar a su rabino en Praga?

El creador que mira su creación es a la vez visto con decepción por quien lo creó a él, límite de lo humano, aún para el artista y su vanidad.

Un aporte directo del escritor al cine sobre este tema es su guión "Los otros", filmado también por Hugo Santiago, sobre un caso de desdoblamiento.

Algo que se observa con frecuencia es que el extrañamiento ante el mundo le permite a Borges verse a sí mismo como personaje de una narración de la que no puede escapar. Esa mutación de la persona en personaje, que tanto hace a la figura fantasmática del ser filmado, reflejado, es también la disolución en la imagen que hacemos y hacen de nosotros. En "Borges y yo" (El hacedor), escribe:

\begin{abstract}
$\mathrm{Al}$ otro, a Borges, es a quien le ocurren las cosas. Yo camino por Buenos Aires y me demoro para mirar el arco de un zaguán y la puerta cancel; de Borges veo su nombre en una terna de profesores. Me gustan los relojes de arena, los mapas, el sabor del café y la prosa de Stevenson. Yo vivo, yo me dejo vivir, para que Borges trame su literatura y esa literatura me justifica. Yo estoy destinado a perderme. Poco a poco voy cediéndole todo. Spinoza entendió que cada cosa quiere perseverar en su ser; la piedra eternamente quiere ser piedra y el tigre un tigre. Yo he de quedar en Borges, no en mí (si es que alguien soy). Hace años yo traté de librarme de él y pasé de las mitologías del arrabal a los juegos con el tiempo y con lo infinito, pero esos juegos son de Borges ahora y tendré que idear otras cosas. Así mi vida es una fuga y todo lo pierdo y todo es del olvido, o del otro. No sé cuál de los dos escribe esta página.
\end{abstract}

\title{
Borges en el cine
}

\section{Cine argentino}

Sobre la esfera que en "El Aleph" se describe como tornasolada, de unos pocos centímetros de diámetro, en la que pueden verse "vertiginosos espectáculos" con la condición de la oscuridad y la vista fija en un punto, han aparecido recientemente notas y libros que le asignan un carácter profético de lo que hoy conocemos como Internet, pero en la configuración de la escena imaginada por Borges quedan invocados los recursos que el escritor experimentó como "tan frecuentador de las salas del biógrafo como de la Enciclopedia Británica".

En cuanto a las versiones audiovisuales que ese mismo relato puede provocar se encuentran dos realizaciones contrastantes: en la película de Javier Torre Un amor de Borges. Jean-Pierre Noher recita a Estela Canto sus visiones en el sótano de la calle Garay, mientras que el videoarte de Narcisa Hirsch "Aleph" propone un minuto inclinado a las abstracciones oníricas y sensoriales que se rematan con 
la voz de la directora.

Han hecho bien Javier Torre y Narcisa Hirsch en dar sus interpretaciones libres y contrastantes, cada uno no hace sino confirmar con su independencia lo inasible y fugitivo del texto. Trampa para cineastas, las visiones desaforadas que propone el cuento ya están en él, el intento de "ilustrarlas" no sería más que una reescritura que dejaría al realizador, en el mejor de los casos, convertido en una suerte de "Pierre Menard, autor del Quijote".

Las ficciones de Borges parecen encerrar en sí mismas su versión cinematográfica, como si el autor se reservara, desde el texto, la película en que podría mutar. El atajo del creador de imágenes será evitar la ilustración del libro, dejarse atravesar por Borges sin intentar capturarlo, beber de la obra para inventar otra.

El mismo Borges elogió la versión cinematográfica de su "Hombre de la esquina rosada", señalando que René Múgica logró una buena película a partir de un cuento menor. En "Borges, biografía verbal", Roberto Alifano recoge el comentario "Creo que Múgica mejoró mi cuento y consiguió algo que yo no había conseguido: hacerlo creíble. Otras cosas con temas míos han fracasado; no he tenido suerte con la gente que hace cine".

Los cuestionamientos no se hicieron esperar con las adaptaciones de "Emma Zunz" en Días de odio, de Torre Nilsson, y la indignación lo asaltó ante la película de Carlos H. Christensen La intrusa, que sugiere una relación homosexual entre los hermanos divididos por una mujer.

De éste último cuento siempre destacó Borges la solución aportada por su madre Leonor Acevedo para la frase de uno de los hombres que remata la acción y que parece extraída de un guión de cine negro: "a trabajar hermano, esta mañana la maté".

Entre las versiones fílmicas que tuvo "La intrusa", que en su original literario tiene a sus protagonistas delineados como dos cowboys de Turdera, difícilmente habría logrado la bendición del autor el antiwestern mexicano de Felipe Cazals "El tres de copas", mientras sí alcanzó a capturar cierto espíritu del cuento el telefilme dirigido por Jaime Chavarri para una serie de Televisión Española. A ese ciclo pertenecen las versiones de "La otra historia de Rosendo Juárez", interpretado por Antonio Banderas; "El evangelio según Marcos", del argentino Héctor Olivera, (que ya había adaptado "El muerto") y "El sur" de Carlos Saura.

No en vano el director español de Cría Cuervos y Prima Angélica, Carlos Saura, apodado "poeta de la memoria" por su probada destreza en generar climas mediante la irrupción de un tiempo pasado en otro presente, o donde una acción imaginaria se impone en la acción principal, fue quien llevó a imágenes el mestizaje de tiempo mental y tiempo físico que experimenta el bibliotecario Dahlmann (Oscar Martínez) que, desde la cama de un hospital, vive simultáneamente su agonía y un viaje al sur bonaerense. Un sur mítico, en busca de unos gauchos verdugos (con recurso de tiempos paralelos que dejan de ser tales para fusionarse en la misma escena -algo muy recurrente en la obra del director-). Luego de la provocación a que lo somete un parroquiano (Gerardo Romano), el atribulado forastero Dahlmann pierde la esperanza pero también el temor. La película de Saura deja en off la prosa de Borges y la acompaña con un final donde al abrirse la puerta de la pulpería también triunfa la artificialidad del fondo rural pintado y luminoso: "Sintió, al atravesar el umbral, que morir en una pelea a cuchillo, a cielo abierto y acometiendo, hubiera sido una liberación para él, en la primera noche del sanatorio, cuando le clavaron la aguja. Sintió que si él hubiera podido elegir o soñar su muerte, ésta es la muerte que hubiera elegido o soñado. Dahlmann empuña con firmeza el cuchillo, que acaso no sabrá manejar, y sale a la llanura". Como se ha señalado antes, este relato tuvo otra versión, Borges, un destino sudamericano, de José Di Zeo, con la participación de Borges como actor en la 
última escena. Otra película que dramatizó cuentos como El Sur, El encuentro y Las ruinas circulares, fue el documental de la BBC Borges y yo filmado en Colonia del Sacramento, durante la guerra entre Argentina e Inglaterra por las Malvinas.

Experto conocedor de la obra de Borges, de quien fue colaborador, Edgardo Cozarinsky dirigió "Guerreros y Cautivas", transponiendo "Historia del guerrero y la cautiva" a la conquista del desierto patagónico en 1880, donde la esposa francesa de un coronel, interpretada por Dominique Sanda, intenta civilizar a una india. El director-escritor dijo buscar deliberadamente una estética ingenua de Billiken para contar una historia espejada de "conversión" no de traición, logrando elogios de la revista Cahiers du Cinema a su fresco épico.

También desde la producción nacional, el tempranamente fallecido director de Nueve reinas y $E l$ aura, Fabián Bielinsky, realizó en los años 80 su cortometraje La espera, un envolvente ejercicio visual con pertinente estructura de "preludio", ya que de preparativos rituales y repeticiones se trata la liturgia de ese hombre, llegado de la Banda Oriental, que se hospeda en una pensión donde imagina y sueña el arribo demorado de su enemigo, hasta que realmente el verdugo lo despierta de su sueño. $\mathrm{Al}$ saberse alcanzado pide que esperen y se da vuelta contra la pared para retomar el sueño de esa misma escena, y "en esa magia estaba cuando lo borró la descarga". Bielinsky hizo lo mismo que en sus largometrajes disfrazados de género policial, sospechar de las apariencias a que nos someten nuestras distorsionadas percepciones, barajar simulacros.

En el cuento "La espera" es Borges quien busca para cada acción un destino narrativo que la justifique: "el hombre pensó que esas cosas (ahora arbitrarias y casuales y en cualquier orden, como las que se ven en los sueños) serían con el tiempo, si Dios quisiera, invariables, necesarias y familiares".

Acerca de los documentales de largometraje o películas biográficas, están aquellas donde sus ficciones aparecen intercaladas con episodios de su vida, y otras en las que el actor que personifica a Borges es también protagonista de algunos de sus relatos. Deben reconocerse los hallazgos de "Los libros y la noche" de Tristan Bauer, para inventar imágenes propias a partir de poemas de Borges como los tableros que surgen como en cajas chinas para el poema "Ajedrez II" o la alteración de escala para que un diminuto Borges -interpretado por Walter San Ana- camine ayudado por su báculo sobre gigantescos libros abiertos mientras se escucha el "Poema de los dones":

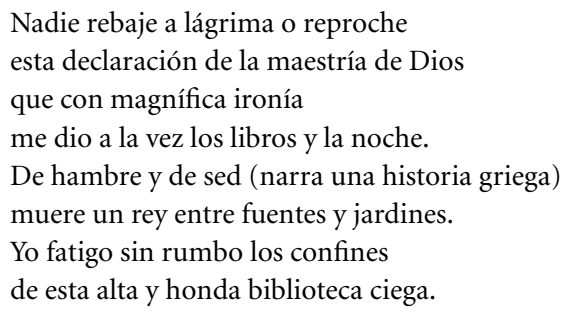

El documental de Eduardo Montes Bradley Harto de Borges, con variados testimonios y material de archivo, aporta una mirada crítica sobre la veneración al escritor. Sin embargo, en su afán desmitificador agiganta su fantasma.

Por el lado de la biopic, El amor y el espanto de Desanzo con Miguel Ángel Sola no alcanza a amalgamar las referencias a la realidad histórica, especialmente a la etapa peronista, con los relatos alucinados del escritor. Una mirada más intimista aunque con momentos caricaturescos ofrece Un amor 
de Borges de Javier Torre, con Jean Pierre Noher, y basado en las memorias de Estela Canto, escritora izquierdista que ve contrariado su romance con el conservador y edípico colega, quien, según una escena memorable de la película, es capaz de negarse al sexo argumentando: "es que yo he sido educado en un universo de infinita respetabilidad".

Pioneros en documentales sobre Borges en los años setenta han sido Mis paseos con Borges, de Adolfo García Videla, y Borges para millones, de Ricardo Wullicher, con algunas escenas dramatizadas y una entrevista al escritor, que incluye fragmentos de otro film aún anterior, Borges, de Luis Bellaba, 1964. De los guiones de Borges y Bioy que llegaron a rodarse ni Los orilleros de Ricardo Luna, ni Los otros de Hugo Santiago, se acercan a lo conseguido por este último director con Invasión, film maldito, de culto, y, para algunos historiadores el mejor film argentino.

\section{El extraño caso del film Invasión}

La imposibilidad que delata Godard de sostener un orden narrativo clásico en sus películas quebradas, discontinuas, donde "puede haber comienzo, desarrollo y fin... pero no necesariamente en ese orden", y la fragilidad e inverosimilitud del héroe, estará presente en un guión de Borges llevado al cine por Hugo Santiago, "Invasión" (1969), -con no pocos ecos godardianos de Alphaville-, aquí Buenos Aires convertida en una ciudad que no existe fuera del cine: Aquilea.

Simulacro de ciudad con resonancias míticas (griegas en su nombre y milongueras en su espíritu), donde se rasguean guitarras y un grupo de valientes resisten a ominosos invasores, uno de ellos entona: "Milonga de Manuel Flores":
Manuel Flores va a morir.
Eso es moneda corriente;
morir es una costumbre
que sabe tener la gente.
Vendrán los cuatro balazos
y con los cuatro el olvido;
lo dijo el sabio Merlín:
morir es haber nacido.
¡Cuánta cosa en su camino
estos ojos habrán visto!
Quién sabe lo que verán
después que me juzgue Cristo.

Según Borges "Invasión” es la leyenda de una ciudad, imaginaria o real, sitiada por fuertes enemigos y defendida por unos pocos hombres, que acaso no son héroes. Luchan hasta el fin, sin sospechar que su batalla es "infinita". La película es una prodigiosa reflexión sobre los recursos expresivos del cine, la iluminación de Ricardo Aronovich, los encuadres precipitados en ángulos inesperados, los movimientos de cámara que generan la acción, la transfiguración de espacios reconocibles de Buenos Aires (la Bombonera, el río) que aparecen enrarecidos en un extrañamiento estético fascinante, y una intriga constantemente dinamitada, enfermiza, a contramano.

Como en un film de aventuras, está el heroico clan de amistades viriles, ("la amistad es un sentimiento tanto más lúcido que el amor, aquí me tienen", dice el dandy al asistir a un bar donde lo esperan sus camaradas), ese grupo de amigos que resistirán en defensa de la ciudad aunque sus habitantes 
permanecen indiferentes ("la ciudad es más que la gente" sentencia el anciano jefe de los decentes). Pero paralelamente se trata de un réquiem al modelo clásico de representación jaqueado por la modernidad: uno de los miembros de la resistencia asiste al cine a ver un western donde triunfan los buenos pero al terminar la función y encenderse las luces de la sala se lo ve inclinado sobre la butaca de adelante, asesinado por una bala cuyo disparo se confundió con los de la pantalla. Es no solo la partida de defunción del happy end sino el crepúsculo del final cerrado, pues la película Invasión no termina después de la palabra "Fin". Se ha perdido el centro y con él se apaga un mundo de códigos genéricos y narrativos. De todos modos, el estilo, como sus personajes, encontrará la manera canónica de morir en su ley. El mujeriego llevado a una emboscada por una mujer declama "Está bien que haya sido una mujer la que me trajo hasta aquí, las he amado y engañado tanto; ahora podré satisfacer una duda que siempre tuve: la de saber si soy valiente, parece que sí. A ver, deje que la señorita se vaya así no ve cosas desagradables".

La película está embarazada de milongas porque a Borges la ciudad, como su música, le parecen espacios y sonidos narrativos y míticos. Se confirman como siluetas de leyendas y fantasmas, que se llaman Muraña, Chiclana, Nicanor Paredes, de Balvanera, Palermo, San Telmo. Le importan como arsenal de mitología, como cartografía del drama, no para ser investigados o explicados desde un prontuario o un expediente burocrático, sino para ser contados, reinventados en el cine, la literatura o la música. En su Historia del Tango (Evaristo Carriego), Borges indica que la música nos revela un pasado ignorado: "No suelo oir 'El Marné' sin recordar con precisión un pasado apócrifo, a la vez orgiástico y estoico. Tal vez la misión del tango sea ésa: dar a los argentinos la certidumbre de haber sido valientes, de haber cumplido ya con las exigencias del valor y el honor".

El arte de la escritura, del cine o de la música, no es para Borges sino pasión bajo el rigor del lenguaje. Se libera del mandato positivista de encorsetar la creación en su función educadora en la razón y la ciencia. Borges le devuelve al arte argentino la libertad de imaginar, fabular y apropiarse de estructuras y mitos universales, que los autóctonos le reprocharán por extranjerizante y los sajones por pretenderse europeo siendo argentino, en vez de quedarse entre papagayos de realismo mágico o descripciones exportables de miseria tercermundista.

Lo mismo vale para el cine, al que Borges propuso coreográficos duelos del malevaje acaso parientes de los gángster de Hollywood que lo embrujaban. Pero si la literatura nativa se reconcilió y reconoció su legado, el cine nacional permaneció más bien refractario al universo borgeano, no digo a intentar versiones o perversiones de sus obras, sino a enriquecerse con sus sugerencias poéticas, tanto más visuales que muchas producciones de cabotaje. Sabido es que Borges no necesita ser "ilustrado" por el cine, sino recreado, tomado como punto de partida, acaso resignándose a reconocer que se trata de una prosa indómita a la que será más provechoso dejarla flotar o pendular inasible entre los fotogramas.

\section{Cine Internacional}

Un caso paradigmático de creación cinematográfica inspirada pero no sofocada por su origen literario es la película de Bernardo Bertolucci, La estrategia de la araña (1969), adaptación del argentino Eduardo de Gregorio de "Tema del traidor y del héroe". La misma narra el viaje de un joven italiano al pueblo paterno, donde descubre que su progenitor no fue un héroe sino un delator de sus camaradas pero convenció a sus traicionados para que lo ejecuten simulando ser fascistas que aniquilan al héroe, durante una función de ópera, para que su muerte sea útil a la rebelión: "ofreceremos el espectáculo de una muerte dramática, un espectáculo teatral del que todo el pueblo, sin saberlo, 
formará parte".

Además de la atmósfera misteriosa que descubrimos desde el punto de vista del visitante, y de la superposición de distintas capas de representación -la ópera, el simulacro de asesinato que sustituye el verdadero ajusticiamiento, la película que pone en escena ambas teatralidades- importa la conclusión del joven protagonista: "pero el mecanismo no era perfecto, porque años después alguien pudo descubrir la verdad para gritarla, a menos que ese alguien mantenga el secreto porque se da cuenta que la obra lo incluye".

Basada en la obra de Umberto Eco, El nombre de la rosa, la película de Jean Jacques Annaud representa al guardián ciego de la biblioteca visitada por Sean Connery y su asistente, con las resonancias borgeanas del libro y le hace pronunciar al anciano ciego "sellaré lo que no debió decirse... en la tumba que seré". Acerca de este laberinto que Eco sitúa justamente en la biblioteca de la abadía, Omar Calabrese en el capítulo "Nudo y laberinto" de La era neobarroca, entiende que es una evidente metáfora de la cultura, pero que el de Borges es un laberinto que proporciona el placer del extravío y la promesa de sentido, mientras el de Eco es un laberinto medieval y que, a su vez, el de la película refiere a la cárceles de Piranesi y a los diseños de Escher ${ }^{9}$.

Martin Scorsese inyectó en la introducción de su Pandillas de Nueva York, algunas apreciaciones que Borges formuló en 1935 sobre la novela de Ashbury, de 1928, en que se basa la película. Las consideraciones borgeanas fueron conocidas por Scorsese, al estar incluidas como prólogo de la edición en inglés. La pieza de Borges, "El proveedor de iniquidades Monk Eastman”, en "Historia Universal de la Infamia”, indica sobre el libro de Herbert Ashbury "tiene la confusión y la crueldad de las cosmogonías bárbaras: sótanos de antiguas cervecerías habilitadas para conventillos de negros, una raquítica Nueva York de tres pisos". Estas y otras consideraciones borgeanas sobre el personaje y el ambiente fueron tenidas en cuenta por Scorsese para The gangs of New York.

Aunque parezca insólito vincular a Mick Jagger con Borges, el "stone" fue ferviente lector de Borges e incluyó citas bibliográficas y visuales en la película psicodélica Performance (1970), de Nicolas Roeg. En ese estado de búsqueda lisérgica de sentido metafísico, abriendo la percepción a otros universos, este film maldito y esotérico que puede ser irritante, tiene a Jagger recitando párrafos de "El sur" y "Tlôn, Uqbar, Orbis, Tertius", y cuando una bala es disparada en el rostro del ídolo surge el retrato de Borges reemplazando las facciones del astro del rock. María Kodama recuerda un encuentro entre Borges y Mick Jagger en un lobby de hotel europeo donde el cantante se presentó innecesariamente como un lector ya que Borges al escuchar su nombre exclamó que conocía muy bien a los Rolling Stones.

Las citas a Borges de Godard responden más claramente a la vocación del director "autor" e iconoclasta pope de la "nouvelle vague" por poner en evidencia los dispositivos de la representación y la narración. Así como Borges toma a la misma literatura como objeto de ficción e inspiración de sus obras, Godard hace lo propio con el cine, no solo como metalenguaje sino como ruptura de la impresión de realidad generada por la cámara y la ilusión de movimiento. En "Alphaville", una ciudad y sus habitantes controlados por una máquina, Godard hace decir a la computadora unas líneas adaptadas de "Nueva refutación del tiempo" (Otras Inquisiciones):

"El tiempo es un río que me arrebata, pero yo soy el río; es un tigre que me devora pero yo soy el tigre. El mundo, desgraciadamente, es real; yo, desgraciadamente, soy Borges".

que en la película se sustituye por "El mundo, desgraciadamente, es real; yo, desgraciadamente, soy Alpha 60". 
El mismo texto aparece en "Paris n'existe pas", de Robert Benayoun, en tanto la protagonista de "Paris nos pertenece", de Rivette, posee la edición francesa de "Otras inquisiciones" y la de "Más allá del amor", de Claude Chabrol, lee Ficciones.

El argentino Hugo Santiago insistió desde París con otro guión de Borges y Bioy en "Los otros" (1974), ya en explícita exhibición de su propio proceso de producción en una aventura intelectual tan exigente como interesante en la disolución de su propio entramado, reflejo atonal y disonante de la melodía irreproducible del cine pretérito que ya no puede ser. Acaso expresión terminal de una época terminal como los años 70 . Constatación de un orden perdido, un orden filmado.

\section{Epílogo}

Es cierto que Borges y las imágenes que de él se desprenden pueden hoy asomar en videoclips del grupo "Cuentos Borgeanos" como "Eternidad", o en el prólogo de la película fellinesca de Roberto Begnini El tigre y la nieve. Pero, como en "El libro de arena", nos sumergimos hoy en una promiscua catarata de imágenes tan impactantes en el instante que se ven como permeables o de baja sedimentación, es decir que forman parte de un libro que impide volver sobre lo ya visto.

Sobre esta confección de imágenes o discursos para el consumo diario, vale recordar el desprecio de Borges por los periódicos que no leía ya que "algo que se escribe para un solo día no debe ser muy importante". En el cine pasteurizado y perecedero que corre por estar al día, sin recordar que un día pasa demasiado pronto, las obras inmortales se resguardan, acaso como el protagonista de "El Aleph" ante su amada ausente, ahora que el mundo había comenzado a alejarse de ella, él podría consagrarse a su memoria, sin esperanza pero también sin humillación. Después de todo fue Borges quien, según Susan Sontag, nos enseñó que "un pesimismo tan profundo como el suyo, tan sereno como el suyo, no necesitaba de la indignación".

Ignoro la suerte de imágenes que nos ofrecerá el futuro, entre ellas las que seguirá inspirando Borges, pero las que hemos visto justifican este y más textos porque las encrucijadas entre Borges y el cine se multiplican.

Me permitiré cerrar estas notas regresando al principio (una manera de salir del laberinto) y a la constatación de que el cine está en Borges antes que Borges en el cine, con un recorte algo antojadizo pero sobre uno de los pasajes más cinematográficos de la literatura borgeana, que se ubica en un sótano de la calle Garay, cumplido el requisito de la oscuridad:

Cerré los ojos, los abrí. Entonces vi. el Aleph. Lo que vieron mis ojos fue simultáneo: lo que transcribiré, sucesivo, porque el lenguaje lo es. Vi una pequeña esfera tornasolada, de casi intolerable fulgor. Al principio la creí giratoria; luego comprendí; que ese movimiento era una ilusión producida por los vertiginosos espectáculos que encerraba. Vi el populoso mar, vi el alba y la tarde, vi las muchedumbres de América, vi un laberinto roto (era Londres), vi todos los espejos del planeta y ninguno me reflejó, vi en un patio de la calle Soler las mismas baldosas que hace treinta años vi en el zaguán de una casa en Fray Bentos, vi racimos, nieve, tabaco, vapor de agua. Vi un cáncer en el pecho, vi. una quinta en Adrogué, vi un globo terráqueo entre dos espejos que lo multiplicaban sin fin, vi caballos de crin arremolinada, una playa en el Mar Caspio, vi los huesos de una mano, una baraja española, vi tigres, bisontes y ejércitos, vi todas las hormigas que hay en la tierra, vi un astrolabio persa, vi un monumento en la Chacarita, vi la circulación 
de mi oscura sangre, vi el engranaje del amor y vi el Aleph, desde todos los puntos, vi en el Aleph la tierra, y en la tierra otra vez el Aleph, vi mi cara, vi tu cara, y sentí vértigo y lloré, porque mis ojos habían visto ese objeto secreto y conjetural, cuyo nombre usurpan los hombres, pero que ningún hombre ha mirado: vi el inconcebible universo".

\section{Notas}

1 Molloy, Sylvia. (2001). Acto de presencia: la literatura autobiográfica en Hispanoamérica, México: Fondo de Cultura Económica.

2 CD. Borges Intimo. Un reportaje de Gloria López Lecube. La Isla FM 89.9. Nota: La broma de Groucho era: “Todo se lo debo a mi bisabuelo, si viviera todo el mundo hablaría de él, pues tendría 127 años".

3 Christ, Ronald. (1967). The Paris Review 40.

4 Reportaje de Pizani, Silvia (en Madrid) a José Luis Di Zeo, Diario La Nación, 8 de mayo de 2007, Buenos Aires.

5 Blanchot, Maurice. (1992). El libro que vendrá, Caracas: Monte Avila.

6 Nuño Montes, Juan Antonio. (1986) La filosofía de Borges, México: Fondo Cultura Económica.

7 Brugger, Ilse. (1943) El problema de la muerte en Rainer María Rilke, Buenos Aires, UBA pp 205-206 (Carta de Rilke a Hulewicz).

8 Borges y Bioy Casares. (1953). Prólogo a Los orilleros-El paraíso de los creyentes, Buenos Aires: Losada.

9 Calabrese, Omar. (1994). La era neobarroca, Madrid: Cátedra.

\section{Referencias Bibliográficas}

AA.VV. (1999). Escrito sobre Borges (Delgado, Josefina, compiladora), Buenos Aires: Planeta.

Alifano, Roberto. (1998). Borges, biografía verbal, Barcelona: Plaza \& Janes.

Bioy Casares, Adolfo. (1983). La otra aventura, Buenos Aires: Emecé.

Borges, Jorge Luis. (1996). Obras Completas, Buenos Aires: Emecé.

Cédola, Estela. (1999). Cómo el Cine leyó a Borges. Edicial: Buenos Aires.

Cozarinsky, Edgardo. (1974). Borges y el cine, Buenos Aires: Sur.

Fuster Lavin, Ana. (2005). Los cuchilleros de Borges detrás de "Pandillas de Nueva York". www.elconfesionario.net.

Ibarra, Cecilia. Borges, la eternidad. www.chasque.net.

Manrupe, Raúl, y Portela, Alejandra. (1995). Un diccionario de films argentinos, Buenos Aires: Corregidor.

Mayer, Marcos. (2007). Biografías de Grandes Creadores: J.L.B. en Revista ñ Clarín, Buenos Aires.

Sontag, Susan. (2006). Cuestión de énfasis, Alfaguara. (reproducida como Carta a Borges, Diario El País, El País Cultural, no 913 , mayo de 2007, Montevideo).

\section{Filmografía}

El tigre y la nieve (aparición de imagen de archivo en el prólogo) de Roberto Benigni, 2007.

Borges, un destino sudamericano de J. L. Di Zeo, 2007.

Ulrica, la memoria de los espejos (guión M. Kodama y M. Casiraghi) de Ignacio Irigoyen, 2007.

Borges y nosotros (corto) de Omar Quiroga, 2007.

Domingo (corto)(de la serie Zoom Buenos Aires, para el canal Ciudad Abierta) de Alberto Farina, 2006.

Pandillas de Nueva York (prólogo inspirado en El proveedor de Iniquidades Monk Eastman, 1935) de Martin Scorsese, 2002. El amor y el espanto de Juan Carlos Desanzo, 2000.

Harto de Borges de E. Montes Bradley, 2000. 
Un amor de Borges de Javier Torre, 2000.

Los libros y la noche de Tristán Bauer, 1999.

El aleph (corto) de Richie Ercolalo, 1999.

El encuentro (corto) de Maximiliano Gerscovich, 1999.

Jorge Luis Borges, una vida de poesía de Fernando Arrabal, 1998.

El milagro secreto (cortometraje) de Leandro Bertoletti, 1998.

La muerte y la brújula (cortometraje) de Jorge Colas, 1998.

Juan Muraña (corto) de Cristian Sabaz, 1997.

Psycho $x$ Borges (corto) de Graciela Taquini, 1994.

La muerte y la brújula (TVE-BBC) de Alex Cox, 1992.

Emma Zunz (TVE-CineTeve France) de Jacques Beinot, 1990.

La intrusa (TVE) de Jaime Chavarri, 1989.

El evangelio según Marcos (TVE) de H. Olivera, 1989.

El sur (TVE) de Carlos Saura, 1989.

La otra historia de Rosendo Juárez (TVE) de Gerardo Vera, 1989.

Guerreros y cautivas (sobre Historia del guerrero y la cautiva) de Edgardo Cozarinsky, 1989.

El tres de copas (sobre La intrusa) de Felipe Cazals, 1986.

Juan Muraña (corto) de Jorge Surraco, 1984.

La espera (corto) de Fabián Bielinsky, 1983.

Borges y yo (Borges and I). Serie de la BBC “Profile of a writer." (dirección David Wheatley), 1982.

La intrusa de Carlos Hugo Christensen, 1979.

Borges para millones de Ricardo Wullicher, 1978.

Los orilleros (guión de Jorge Luis Borges y Adolfo Bioy Casares) de Ricardo Luna, 1975.

Más allá del amor/Alice ou la derniére fugue (la heroína lee Ficciones) Claude Chabrol, 1977.

Los paseos con Borges de Adolfo García Videla, 1977.

El muerto de Héctor Olivera, 1977.

Les autres (guión de Jorge Luis Borges y Adolfo Bioy Casares) de Hugo Santiago, 1973.

La estrategia de la araña/Strategia del ragno (Tema del traidor y del héroe) de Bernardo Bertolucci, 1970.

Performance. (cita a Tlön. y aparición de imagen de Borges) de Donald Cammell y Nicolas Roeg, 1970.

París n'existe pas, (texto de "Nueva Refutación del tiempo" en un cartel final) de Robert Benayoun, 1969.

The Innerworld of Jorge Luis Borges de Harold Mantell, 1969.

Invasión (guión de Jorge Luis Borges y Adolfo Bioy Casares) de Hugo Santiago, 1969.

Emma Zunz (TVFrancesa) de Alain Magrou, 1968.

Alphaville (cita a "Nueva refutación del tiempo") de Jean-Luc Godard, 1965.

Borges (corto) de Angel Bellaba, 1964.

Hombre de la esquina rosada de René Múgica, 1962.

París nos pertenece/Paris nous appartient (cita a Otras Inquisiciones) de Jacques Rivette, 1960.

Días de odio (Emma Zunz) de Leopoldo Torre Nilsson, 1960.

Juan Muraña comentado por su autor (corto) de Amanda Ortega y María Kodama.

\section{Programas de televisión}

Domingo (de la serie de Ciudad Abierta "Zoom Buenos Aires") con citas a "Invasión”, de Alberto Farina, 2008. De películas. Entrevista del autor a María Kodama, para Canal 21, Bs.As., 2008. 
Los conjurados. Producción Fernando Flores. Fundación Internacional J. L. Borges, 2006.

DNI - J.L.Borges, 2000.

Borges. Entrevista de Raúl Burzaco, 1982.

A fondo. Entrevistas de Soler Serrano a Borges para TVE, 1977 y 1982.

Summary: Besides the transpositions and Borges quotes in movies by Torre Nilsson, Saura, Mick Jagger, Scorsese, Godard, Christensen, Bertolucci, Hugo Santiago, Chabrol, Bielinsky, Mugica, Cozarinsky, Javier Torre, Bauer, Narcisa Hirsch or Desanzo; we find the opinions of Borges as cinematographic critic on Groucho Marx, Eisenstein, Ford, Soffici, Orson Welles, Hitchcock, the dubbing, the argentine cinema; its preference for westerns and gangsters movies by the viennese baroque Von Sternberg - perhaps Hollywood relatives of its porteños cutlers-, and his work like scriptwriter. Defender of classic cinema instead of "new cinema" that was interested in him, Borges made cinema from its literature. The model, grammar or narrative system of cinema (¿magic?) that orders chaos in the frame and the mounting get through his work, oriented as well forward projected worlds and revealing mirages.

Keywords: appointments - circularity - cosmogony - Labyrinths - mirrors - mounting - scenes - synthesis.

Resumo: Além das transposiçoes e citas borgeanas no filmes de Torre Nilson, Saura, Mick Jagger, Scorsese, Godard, Christensen, Bertolucci, Hugo Santiago, Chabrol, Bielinsky, Mugica, Cozarinsky, Javier Torre, Bauer, Narcisa Hirsch o Desanzo; encontramos as opinioes de Borges enquanto crítico cinematográfico sobre Groucho Marx, Eisenstein, Ford, Soffici, Orson Welles, Hitchcock, a dublagem, o cinema argentino; sua preferência pelos westerns e pelo cinema de gangsters do barroco vienês Von Stenberg - talvez parentes hollywoodense de seus cuchilleros porteños - e seu labor como roteirista. Defensor do cinema clássico antes que do novo cinema que se interessou nele, Borges fez cinema desde sua literatura. O modelo, gramática ou sistema narrativo do cinema (¿magia?) que ordena o caos no enquadre e a montagem atravessam sua obra, tao inclinada também por mundos projetados e miragens reveladoras.

Palavras chave: cena - circularidad - cita - cosmogonía - espelho - labirintos - montagem - síntese. 